\title{
Coliforms and Helminth Eggs Removals by Coagulation-Flocculation Treatment Based on Natural Polymers
}

\author{
Evelyn Zamudio-Pérez ${ }^{1}$, Neftalí Rojas-Valencia ${ }^{2}$, Isaac Chairez ${ }^{1}$, Luis Gilberto Torres ${ }^{1 *}$ \\ ${ }^{1}$ Bioprocesess Department, UPIBI-Instituto Politécnico Nacional, Barrio la Laguna Ticomán, Mexico \\ ${ }^{2}$ Engineering Institute UNAM, Environmental Engineering Department, Coyoacán, Mexico \\ Email: *LTorresBustillos@gmail.com
}

Received April 16, 2013; revised May 18, 2013; accepted June 16, 2013

Copyright (C) 2013 Evelyn Zamudio-Pérez et al. This is an open access article distributed under the Creative Commons Attribution License, which permits unrestricted use, distribution, and reproduction in any medium, provided the original work is properly cited.

\begin{abstract}
Wastewater from a municipal wastewater treatment plant (Mexico) was treated by a coagulation-flocculation using natural gums. The residual water was characterized in terms of organic load, and biological contaminants, i.e. total Coliforms (TC), fecal Coliforms (FC) and helminth eggs (HE). The sample has values of $2.8 \times 10^{7} \mathrm{MPN} / 100 \mathrm{ml}, 8.48 \times$ $10^{6} \mathrm{MPN} / 100 \mathrm{ml}$ and $470 \mathrm{HE} / \mathrm{L}$ is regarded to TC, FC and HH, respectively. The HE identified in the wastewaters were Diphyllobothrium latum, Ascaris lumbricoides, Hymenolepis nana and Toxocara canis. From several gums, Hydroxypropyl triammonium chloride guar gum (HPTAC-guar) was selected as the most adequate coagulant-flocculant for the class of municipal wastewater (MWW). A diminution of $82 \%$ for TC, $94 \%$ for FC and $99 \%$ for HE was obtained. Besides, the reduction of chemical oxygen demand (COD) and turbidity removals were $46 \%$ and $39 \%$ respectively. The natural gum mixed with $\mathrm{Ca}(\mathrm{OH})_{2}$, obtained removals of $52 \%$ for TC, $100 \%$ for $\mathrm{HE}, 47 \%$ for $\mathrm{COD}$ and $30 \%$ for turbidity.
\end{abstract}

Keywords: Coagulation; Fecal Coliforms; Flocculation; Helminth Eggs; Total Coliforms; Wastewaters

\section{Introduction}

Recent studies of two more important Mexico City wastewater flows demonstrated that MWW is having a medium-weak charge with strong bacteriological characteristics, high alkalinity and mineral content [1]. Bacteriological factors and global epidemiological studies on the use of wastewater for agricultural purposes, particularly in Latin American countries, have shown a great public health risk by gastrointestinal diseases such as diarrhea, caused by the presence of viruses, bacteria, protozoa and helminth eggs [2].

Pathogens in water infect approximately 250 million people each year, resulting in $10 \pm 20$ million deaths. The microbial pathogen concentrations are different depending of many factors such as the month in the year, the specific zone, etc. Thus, determining the number of different microbial pathogens in a sample of water or wastewater is essential to prevent or control a feasible epidemic [3]. Not all countries have HE in wastewater or slu-

${ }^{*}$ Corresponding author. dges (Table 1 gives an insight on this fact in some countries). Based on epidemiological studies, the world health organization (WHO) recommends a criterion of $\leq 1 \mathrm{HE} /$ $\mathrm{L}$ in wastewater used for irrigation without using drip irrigation crops eaten without cooking [4].

Many scientific studies have been focused on the removal of bacteria (total and fecal coliforms) and HE as biological indicators of water microbiological quality [5]. Most of these works can be divided into two clear classifications. Those works are oriented to water or wastewater disinfection with acids [6], alkalis , radiations [7], ozone [2], etc. The second group contains reports of the removal efficiencies for physicochemical or biological systems which were designed for solids, carbonaceous or nitrogenated material removals, with a no controlled degree of elimination efficiency for bacteria and/or pathogenic parasites.

Physical methods have been employed for removing (not inactivation) many pathogens in waters and wastewaters. Among others filtration, sedimentation, coagulation-flocculation and the use of membranes can be men- 
Table 1. Helminth egg content in waste waters and sludges at different countries.

\begin{tabular}{cc}
\hline Country-region & HE/L in municipal wastewater \\
\hline Developing countries & $700-3000$ \\
Brazil & $166-202$ \\
Chine & 840 \\
Egypt & $6-42$ \\
Island of Grand Cayman & $100-1230$ \\
Jordan & 300 \\
Mexico & $6-98$ Cities \\
Morocco & 840 \\
South Africa & 772 \\
Syria & 800 \\
Tunisia & 30 \\
Ukraine & 60 \\
France & 9 \\
Japan & 80 \\
United States of America & $1-8$
\end{tabular}

Adapted from Jimenez and Maya-Rendon (2007).

tioned [5]. Jimenez et al. [8], reported the use of sand and synthetic medium filtration of advanced primary treatment effluent from Mexico City for the elimination of HE. The sand and fuzzy filters removed the $70 \%$ and $91.3 \%$ of $\mathrm{HE}$ (initially $22.7 \mathrm{HE} / \mathrm{L}$ ), respectively, but no reduction of FC was observed $(76.5 \%$ and $88.4 \%$ of the TSS were removed). Jimenez and Maya-Rendon [5] established that membrane bioreactors (99.99\%), dualmedia filtration (99\%), coagulation-flocculation as tertiary treatment $(99 \%)$ and granular sand filtration $(99 \%)$ are the methods with higher efficiencies for HE removal. The removal of simulated helminth eggs by micro screening $(98.95+/-0.83 \%$ of samples containing between 74.37 and 77.13 eggs/L) was studied [9]. The simulated wastewaters contained $20 \mathrm{~mm}$ latex spheres with size distribution and densities very similar to those observed for HE. Sengupta et al. [10], studied the natural sedimentation of HE. These authors found that the measured settling velocities for these eggs were in average $0.0612,0.1487$ and $0.1262 \mathrm{~m} / \mathrm{h}$. Nouri et al. [11], reported the removal of Ascaris spp. and Fasciola hepatica eggs from drinking water using the horizontal (HRF) and downflow (DRF) roughing filters. For Fasciola hepatica, HRF and DRF filters were capable of eliminating up to $91.3 \%$ and $82.1 \%$ of the initial amount of eggs at the lower filtration rate $(0.5 \mathrm{~m} / \mathrm{h})$. In the case of Ascaris spp., the filters removed up to $60.7 \%$ and $57.3 \%$, again, at the lower filtration rate $(0.5 \mathrm{~m} / \mathrm{h})$.

Biological methods for $\mathrm{HE}$ and $\mathrm{FC}$ elimination are less utilized in wastewater treatments. Cabirol et al. [12], reported the HE and FC removal by anaerobic thermophilic sludge digestion. They achieved coliforms removals of $1000 \mathrm{MPN} / \mathrm{gTS}$ and HE diminished to $0.28 \mathrm{HE} / \mathrm{gTS}$. Von Sperling et al. [13], reported a good COD removal with efficiencies ranging from $69 \%$ to $84 \%$ for the UASB reactor, from $43 \%$ to $56 \%$ for the activated sludge systems only and from $85 \%$ to $93 \%$ for the overall system. La Motta et al. [14], describe the use of a combined UASB/aerobic solid contact system for the treatment of municipal wastewater; the UASB reactor has a total COD removal efficiency of $34 \%$, and the result indicates $36 \%$ to TSS. Guo et al. [15], studied the effect to the bioaugmentation in biological tanks at low temperatures, the removal efficiency was $84 \%$ for COD with an optimal temperature between $13^{\circ} \mathrm{C}$ and $23^{\circ} \mathrm{C}$. Reinoso et al. [16], reported HE, TC and fecal streptococci removals founded in facultative ponds $(92.46 \%, 84.82 \%$ and $89.61 \%)$, surface flow wetlands $(>99.99 \%, 36.07 \%$ and $61.97 \%)$ and subsurface flow wetlands $(0 \%, 69.27 \%$ and $54.67 \%)$. Biological aerated filter (BAF) is an effective bioreactor that provides a small footprint process at various stages of wastewater treatment. Liu et al. [17], reported a COD removal of $85.1 \%$ when the hydraulic retention time was longer to $4 \mathrm{~h}$, and $65.7 \mathrm{~h}$ to $2 \mathrm{~h}$, when oyster shell was applied as the media to the filter.

Finally, chemical methods have shown higher removal efficiencies. However, their unitary cost of FC and HE removal is the highest compared to all other wastewater treatments. Rojas-Valencia [18] reported that ozone destroyed a wide variety of microorganisms (Escherichia coli was removed 4 logs), including biological indicators (TC, FC with a removal of 2 - 3 logs, Streptococcus, Salmonella, etc.) as well as algae, bacteria, fungi, virus and HE ( $81 \%$ and $94 \%)$. Lin et al. [19], reported the use of $\mathrm{UV}$ irradiation and the $\mathrm{UV}-\mathrm{TiO}_{2}$ such effective to inactivate microorganisms in wastewater disinfection, reported a TC removal of $96.78 \%$ (UV) and $93.32 \%\left(\mathrm{UV}-\mathrm{TiO}_{2}\right)$. Bhatti et al. [20], integrated chemical treatment using waste hydrogen peroxide and UV light about $93 \%$ COD, $90 \%$ BOD and $83 \%$ turbidity reduction and complete disinfection coliform bacteria occurred when $40 \%$ waste $\mathrm{H}_{2} \mathrm{O}_{2} / \mathrm{UV}$ was used. García et al. [21], studied the effect in the $\mathrm{HE}$ inactivation with homogeneous photocatalysis. The Ascaris eggs were $79 \%$ inactivated with $\mathrm{He} / \mathrm{H}_{2} \mathrm{O}_{2}$ and $36 \%$ with $\mathrm{Co}_{2}+/ \mathrm{PMS}$ with an irradiation to $800-900$ $\mathrm{W} / \mathrm{m}^{2}$.

Mijaylova et al. [1], reported for the Gran Canal and the deep drainage flows, average total coliforms values of $1.5 \times 10^{8}$ and $3.4 \times 10^{8}$ MPN100 mL, respectively, while for HE, the average values were of 41 (24 - 56) and $44(24-84)$ eggs/L. Though the work was not focused on the treatment of the coliforms and HE, the authors reported that the use of $\mathrm{FeCl}_{3}$ plus a given synthetic poly- 
mer removed the total of the $\mathrm{HE}$ present in the original wastewater samples $(100 \%)$, not all the TC and FC (residual coliform values between $10^{8}$ and $10^{9} \mathrm{MPN} / 100 \mathrm{ml}$ were observed after the coagulation-flocculation process).

Among the chemical processes currently used in treating, wastewater coagulation-flocculation has received considerable attention for obtaining a high level of contaminant removal [22]. Nowadays the most commonly used coagulants-flocculants are salts of $\mathrm{Fe}^{+3}$ and $\mathrm{Al}^{+3}$. However, their mechanisms are complex and depend on a big number of variables (cation concentration and $\mathrm{pH}$ ) [23]. The effect of the interaction between the coagulant dose and $\mathrm{pH}$ on the removal of the SST and SVI is significant, while no such interaction has been seen between them and water recovery [24].

The use of biopolymers in the coagulation-flocculation process can produce more biodegradable sludge. Indeed, it is not necessary to adjust the $\mathrm{pH}$ in the wastewater to obtain good wastewater removals. Natural gums for industrial use are the starches, pectins, galactomannans and exudates such as natural rubber and natural gums (Arabic and mesquite are good examples), which are substances of plants widely used in food, pharmaceutical, textile, cosmetics and wine [25]. Carpinteyro-Urbán et al. [26], have reported the use of guar gum, locust bean gum, mesquite and Opuntia mucilage flocculants coagulants agents in the treatment of MWW. The adequate determination of coagulant and dose not only improve the characteristics of resulting water but also reduce the treatment cost.

Our research group has reported the use of natural coagulant-flocculant agents, such as guar and locust bean gums, Prosopis laevigata seed gum, Annona (muricata, diversiforme and cherimola) seed gum and Opuntia ficus-indica mucilage [27-30]. MWW and industrial wastewaters were successfully treated with reasonable COD and turbidity removals, low production of sludges and good sludge settleability properties.

Some authors [7,31] have reported the use of lime for the treatment of sewage sludges, by mixing the effect of $\mathrm{pH}$ adjust and high temperatures. As far as we know, there are no works of coagulation-flocculation being employed together with lime for disinfection purposes in wastewaters.

The aim of this work was to demonstrate the feasibility of treating MWW from Mexico City using coagulationflocculation process and a galactomannan-type polymer to reduce the organic load and the pathogens indicators (TC, FC and HE).

\section{Materials and Methods}

\subsection{General Characterization of the MWW}

The wastewaters employed in this work were collected from the inflow of the San Juan Ixhuatepec treatment plant, located in the State of Mexico. Wastewater was sampled twice (120 L each time) in the plant prior to the regular treatment applied to the MWW. The sampled wastewaters were stored at $4^{\circ} \mathrm{C}$. The general characterization of MWW was performed by measuring the physicochemical and microbiological parameters established in the Mexican Official Standard [32,33]. The relevant parameters were $\mathrm{pH}, \mathrm{COD}$, Turbidity, TC, FC and HE. The NOM-001-ECOL-1996 considers that FC and HE are the pathogenic contaminants to be determined in MWW. For the goal of this study these microbiology indicators were analyzed.

\subsection{Determination of Sludge Volume and $\mathrm{Z}$ Potential}

Additionally, sludge was measured using Imhoff cones by allowing $1 \mathrm{~L}$ samples to settle down for 1 hour. $\mathrm{HE}$ were measured according to the Mexican Norm [34]. The Z-potential was determined at the original $\mathrm{pH}$ of the sample using a commercial Z-meter (Malvern, USA). For the sake of completeness, the method for determining TC, $\mathrm{FC}$ and $\mathrm{HE}$ are described below.

\subsection{Coliforms Quantification}

The method is based on direct filtration of a sample or aliquot of the sample through a cellulose membrane which retains the organisms, either by placing the membrane in a selective culture medium $\mathrm{m}$ Endo agar LES (for growth of TC) or $\mathrm{m} \mathrm{FC} \mathrm{agar} \mathrm{(for} \mathrm{FC} \mathrm{growth).} \mathrm{The}$ membrane is incubated for 24 hours either at $35^{\circ} \mathrm{C}-37^{\circ} \mathrm{C}$ for the detection of coliform organisms, or alternatively to $44.0^{\circ} \mathrm{C} \pm 1{ }^{\circ} \mathrm{C}$ for the presence of thermo-tolerant coliform organisms. A direct count of the colonies developed on the membrane prepared with a selective culture medium was performed [35].

\subsection{Helminth Eggs Quantification}

This method is based on the concentration and removal of HE by combining the principles of the method and the biphasic flotation method. A volume of $5 \mathrm{~L}$ was taken from wastewater. The sample was allowed to stand for 8 hours, the supernatant was aspirated by vacuum and discarded. The sediment was filtered in a sieve with $160 \mathrm{mi}-$ cron. Pore sieve is washed with $5 \mathrm{~L}$ of water and recovered wash water along with the sediment filter. The sample was allowed to stand overnight, aspirated supernatant carefully as possible. The sediment was deposited in the centrifuge containers rinsing 3 times the little jug perfectly with distilled water and placing it in containers for centrifugation. The tubes were centrifuged at $400 \mathrm{~g}$ by 5 min. The supernatant was decanted by vacuum ensuring that bottom of the tablet container was empty. The pellet 
was resuspended in $150 \mathrm{ml}$ of solution of zinc sulfate $\left(\mathrm{ZnSO}_{4}\right)$. All pellets were centrifuged at $400 \mathrm{~g} 5 \mathrm{~min}$, and the supernatant was recovered by pouring it into a plastic container of $2000 \mathrm{ml}$. The sample was diluted in $1000 \mathrm{ml}$ of distilled water and allowed to settle overnight. The maximum was aspirated by vacuum supernatant and the pellet resuspended with a little distilled water. The suspension was centrifuged at $480 \mathrm{~g}$ for $3 \mathrm{~min}$. The supernatant was decanted and the pellet was resuspended with distilled water by centrifuging at $480 \mathrm{~g}$ for $3 \mathrm{~min}$. The supernatant was decanted and the pellet was resuspended in $15 \mathrm{ml}$ of the acid-alcohol solution using a shaker. The tubes were added to $10 \mathrm{ml}$ of ethyl acetate and uncovering gently stirring occasionally to strip the gas. The sample was centrifuged at $660 \mathrm{~g}$ for $3 \mathrm{~min}$ and the supernatant aspirated as much as possible. Finally, less than $1 \mathrm{ml}$ was left in the tube. Loss of the wafer was prevented. The pellet was homogenized and quantification proceeded directly by microscopy. A visual identification of structures finalized the HE determination [34].

\subsection{Natural Gums Selection Process}

Coagulation-flocculation process were developed using square jars with $2 \mathrm{~L}$ capacity with a speed of $100 \mathrm{rpm}$ for $3 \mathrm{~min}$ (coagulation process) and then at $20 \mathrm{rpm}$ for 15 min (flocculation process). Five natural gums were used as coagulant-flocculant: locust bean gum, guar (Drogueria Cosmolpolita, Mexico), Delonix regia (flamboyan) seed, Hydroxypropyl triammonium chloride guar gum HPTAC-guar (Conjunto Lar, S.A. de C.V, Mexico) and Prosopis laevigata (mezquite) seed gums. The $\mathrm{FeCl}_{3}$ (J.T. Baker, Mexico) as a pure chemical agent was used for comparison purposes.

In particular, Hidroxypropyl-triamonium chloride-guar (HPTAC-guar) is a cationic derivative of guar gum and it is sold as Cosmedia Guar ${ }^{\mathrm{TM}}$. This product is frequently employ as a humidifier agent in shampoos and hair conditioner products. The structure of HPTAC-guar is presented at Figure 1. Four different concentrations (25, 50, 75 and $100 \mathrm{mg} / \mathrm{L}$ ) of each coagulant-flocculant agent were assessed in order to choose the best one as well as its dose. Parameters such as COD and turbidity removal, $\mathrm{pH}$, conductivity, sludge accumulation, TC, FC and HE removal were evaluated in selecting the best natural coagulant-flocculant.

Once the best natural coagulant-flocculant was selected, a second set of experiments with different concentrations of the elected gums (25 30, 40, 50 and $60 \mathrm{mg} / \mathrm{L})$ was performed. This strategy was followed to optimize the gum dose (all these analyses were performed by triplicate). Once again, the parameters measured included COD removal, turbidity reduction, $\mathrm{pH}$, conductivity, sludge formation and removal of biological indicators (TC, $\mathrm{FC}$, and HE).

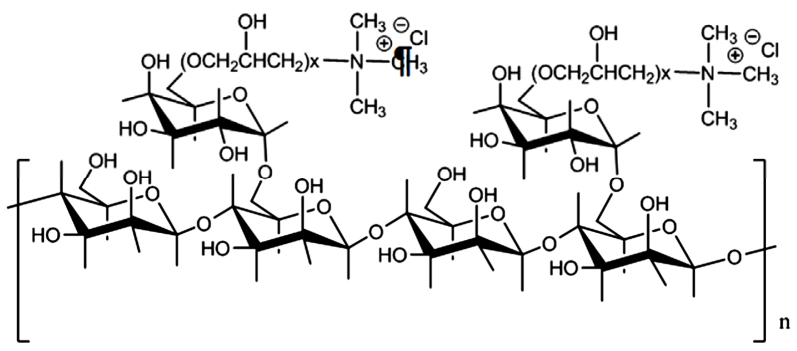

Figure 1. Structure of HPTAC-guar.

\subsection{Mixed Biological/Chemical Coagulant for MWW Treatment}

The initial $\mathrm{pH}$ of the MWW was changed using different concentrations of $\mathrm{Ca}(\mathrm{OH})_{2}$ (industrial grade) prepared with a concentration of $4 \%$. This compound also serves as a coagulating agent. After the $\mathrm{pH}$ modification, the flocculation-coagulation process was done using the best dose concentration of the selected natural gum. The parameters analyzed in these tests were same considered in the previous studies. This process was also performed in triplicate.

\section{Results and Discussion}

\subsection{Characterization of the MWW}

The characterization of the physicochemical and microbiological MWW is shown in Table 2 (two water batches). Regarding the $\mathrm{pH}$ value, MMW is slightly acid. In this analysis the COD value for MWW is twice the COD value reported for others wastewaters from effluents generated in Mexico City [1]. Furthermore, FC, TC and HE are ten times the reported in the same study. In this sense, the wastewater samples are considered as highly contaminated. Regarding the MBAS concentration for MWW, the value is twice the value reported in the previous study.

Z-potential was measured for designing coagulatio nflocculation systems. The MWW has Z-potential positive (i.e., +15.73 ) at the fixed $\mathrm{pH}=6.76$. This implies that the net charge of the MWW is positive and should be treated by anionic flocculants. This characteristic is adequate to perform the flocculation-coagulation based on natural gums.

TC for the MWW sample were about $2.8 \times 10^{7}$ $\mathrm{MNP} / 100 \mathrm{ml}$ that is significative higher than the one obtained in previous studies. These values were obtained by measurements averaged from samples obtained in various days and various sampling times. On the counterpart, FC showed a value of $8.48 \times 10^{6}$.

The number of HE found in the first batch MMW (470 HE/L) must be highlighted. The concentration corresponds to the values reported in Mexican rural or periurban areas [4]. However, this value is higher than those 
Table 2. Physico-chemical and microbiological characterization of the MWW.

\begin{tabular}{ccc}
\hline Parameter & Unity & Value range \\
\hline pH & $\mathrm{pH}$ Unities & $6.76-7.49$ \\
Turbidity & $\mathrm{FAU}$ & $141-107$ \\
Total solids & $\mathrm{mg} / \mathrm{L}$ & 890.90 \\
Conductivity & $\mu \mathrm{s}$ & $1335-1982$ \\
Color & $\mathrm{Pt} / \mathrm{Co}$ & 1450 \\
BOD 5 & $\mathrm{mg} / \mathrm{L}$ & 403.76 \\
Hardness & $\mathrm{mg} / \mathrm{L}$ & 258.21 \\
Total alkalinity & $\mathrm{mg} / \mathrm{L}$ & $\mathrm{NR}$ \\
(as CaCO & & \\
COD & $\mathrm{mg} / \mathrm{L}$ & $970.0-825.00$ \\
MBAS & $\mathrm{mg} / \mathrm{L}$ & 11.61 \\
Al & $\mathrm{mg} / \mathrm{L}$ & - \\
Cr & $\mathrm{mg} / \mathrm{L}$ & $<0.01$ \\
Fe & $\mathrm{mg} / \mathrm{L}$ & 0.247 \\
Pb & $\mathrm{mg} / \mathrm{L}$ & 0.078 \\
Z-Potential & $\mathrm{mV}$ & $15.73^{*}$ \\
Total Coliforms & $\mathrm{MPN} / \mathrm{mL}$ & $2.8 \times 10^{7}-7.2 \times 10^{6}$ \\
Fecal Coliforms & $\mathrm{MPN} / \mathrm{mL}$ & $8.48 \times 10^{6}-5.5 \times 10^{4}$ \\
Helmint eggs & $\mathrm{HE} / \mathrm{L}$ & $470-12$ \\
\hline
\end{tabular}

*At the original $\mathrm{pH}=6.76$ units.

obtained in other works. From this value, it can be assumed that the San Juan Ixhuatepec wastewater treatment plant could receive anonymously effluents from a hospital or slaughterhouse facilities (even when it is supposed to receive municipal wastewaters exclusively).

It is well known that HE as other biological contaminants present a variation along the days of the year and the hour of the day, when the sample was taken [1]. HE species found in the MWW were Diphyllobothrium latum, Ascaris lumbricoides, Hymenolepis nana and Toxocara canis. A brief description of every kind of HE found in MWW is given in the following paragraphs.

Diphyllobothrium latum: The HE have 67 to $71 \mathrm{mi}-$ crons in length and 40 to 51 um wide [36]. Fish in lakes are often heavily infected by this worm [37]. In humans, these organisms can lead to nonspecific abdominal symptoms and a small percentage of cases is developing macrocytic hypochromic anemia (Figure 2(a)) [36]. On the other hand The Ascaris lumbricoides: HE size is from 45 to 75 microns long and 35 - 50 microns wide [38]. The most common symptom in infected patients is vague abdominal pain, the larvae come to cause sensitization of the host, causing reactions such as pulmonary infiltrates,

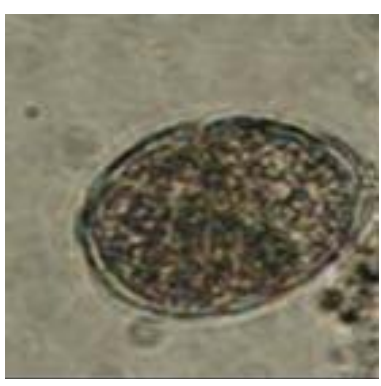

(a)

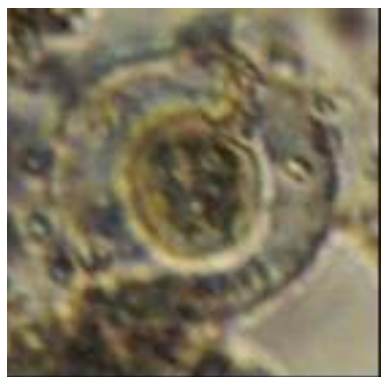

(c)

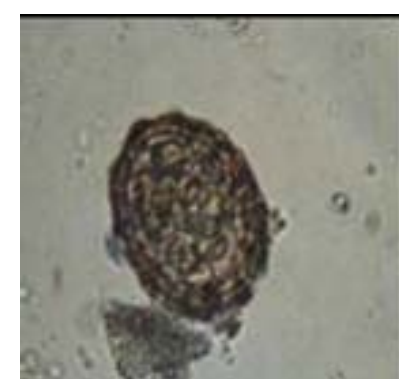

(b)

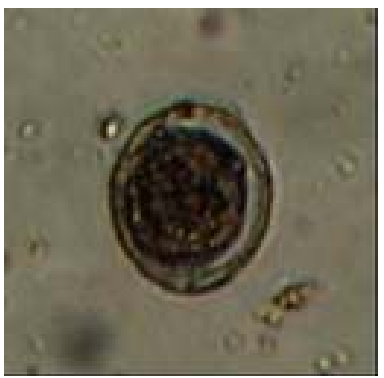

(d)
Figure 2. Microphotographies of helminth eggs found in the MWW sample.

asthma attacks and edema of the lips (Figure 2(b)) [37]. Hymenolepis nana: HE size of 30 to 44 microns [38]. This parasite has a cycle of internal autoinfection. Mild cases are usually asymptomatic, the larval forms destroy injures villi, adults irritate the intestinal wall, causing a mild enteritis: cases with moderate or massive parasitization abdominal pain, nausea, vomiting, weight loss, diarrhea, nervousness, headache, etc. (Figure 2(c)) [39]. Finally, Toxocara canis: HE measure 90 microns long and 75 microns wide [37]. Toxocariasis is a clinical syndrome that is caused by the invasion of human viscera by larvae. These parasites are roundworms of dogs and cats. In humans, the larvae released from ingested embryonated eggs, penetrate the intestinal mucous membrane and travels to the liver, lungs and other organs. The primary lesion is found in the liver and may have extensive necrosis of liver parenchyma. Lesions that contain the larvae of Toxocara found in liver, brain, eye, spinal cord, lungs, heart muscle, kidneys and lymph nodes. The disease occurs in children under 4 years of age (Figure 2(d)) [37].

Mijaylova et al. [1], reported the predominance of Ascaris eggs in the GC and DD in the range of $20-52$ eggs/L, however Enterobius spp, Hymenolepis nana, Taenia spp, Necator spp, and Trichuris were also detected at concentrations of $0-8$ eggs/L.

\subsection{Selection of Natural Gum in the Process of Coagulation-Flocculation}

The parameters analyzed for the selection of both natural 
gums and the doses were COD and turbidity. The natural gum showing higher COD removal $(45.6 \%)$ and turbidity $(19.3 \%)$ values was HPTAC-guar at the concentration of $50 \mathrm{mg} / \mathrm{L}$. These removal values were higher than those obtained when using $\mathrm{FeCl}_{3}$ and all others natural gums.

Regarding the generation of sludges, it is quite noticeable that natural gums produced less sludge than $\mathrm{FeCl}_{3}$ (in the range of $0-0.5 \mathrm{~mL} / \mathrm{L}$ while $\mathrm{FeCl}_{3}$ produced 1-3 $\mathrm{mL} / \mathrm{L})$. Microbiological removals obtained by using Prosopis laevigata (mesquite) seed gum and HPTAC-guar (both at a concentration of $100 \mathrm{mg} / \mathrm{L}$ ) reached the full elimination of both TC and FC (Table 3), while $\mathrm{FeCl}_{3}$ at the $75 \mathrm{mg} / \mathrm{L}$ removed only the $100 \%$ of $\mathrm{FC}$, but only $83.7 \%$ of TC.

Table 3. Removal of chemical and microbiological parameters in the MWW after coagulation-flocculation process using different natural gums. Initial HE concentration was 470 HE/L.

\begin{tabular}{|c|c|c|c|c|c|c|}
\hline $\begin{array}{c}\text { Natural gum } \\
\text { or salt }\end{array}$ & $\begin{array}{c}\text { Dose } \\
(\mathrm{mg} / \mathrm{L})\end{array}$ & $\begin{array}{c}\text { COD } \\
\text { removal } \\
(\%)\end{array}$ & $\begin{array}{c}\text { Turbidity } \\
\text { I removal } \\
(\%)\end{array}$ & $\begin{array}{c}\text { Sludge } \\
\text { production } \\
(\mathrm{mL} / \mathrm{L})\end{array}$ & $\begin{array}{c}\text { TC } \\
\text { 1removal } \\
(\%)\end{array}$ & $\begin{array}{c}\text { FC } \\
\text { Iremoval } \\
(\%)\end{array}$ \\
\hline \multirow{4}{*}{$\begin{array}{l}\text { Delonix } \\
\text { regia seed } \\
\text { gum }\end{array}$} & 25 & 1.92 & 11.32 & 0 & - & - \\
\hline & 50 & 0 & 1.05 & 0 & - & 9.83 \\
\hline & 75 & 0 & 0 & 0 & 65.69 & 0 \\
\hline & 100 & 0 & 0 & 0.1 & 6.94 & 11.65 \\
\hline \multirow{4}{*}{$\begin{array}{l}\text { Prosopis } \\
\text { laevigata } \\
\text { seed gum }\end{array}$} & 25 & 0 & 20.75 & 0 & - & - \\
\hline & 50 & 8.8 & 2.6 & 0 & 72.02 & 0 \\
\hline & 75 & 0 & 0 & 0 & 90.24 & 83.87 \\
\hline & 100 & 0 & 0.98 & 0.2 & 100 & 100 \\
\hline \multirow{4}{*}{ Guar gum } & 25 & 15.28 & 19.8 & 0 & - & - \\
\hline & 50 & 4.4 & 3.47 & 0 & 67.52 & 37.18 \\
\hline & 75 & 0 & 0 & 0 & 41.83 & 84.95 \\
\hline & 100 & 0 & 0 & 0.3 & 81.84 & 100 \\
\hline \multirow{4}{*}{$\begin{array}{l}\text { Locust bean } \\
\text { gum }\end{array}$} & 25 & 0 & 10.38 & 0 & - & - \\
\hline & 50 & 25 & 9.6 & 0 & 0 & 14.10 \\
\hline & 75 & 0 & 1.37 & 0 & 51.22 & 0 \\
\hline & 100 & 0 & 0 & 0.5 & 52.78 & 99.3 \\
\hline \multirow{4}{*}{ HPTAC-guar } & 25 & 5.77 & 19.8 & 0 & - & - \\
\hline & 50 & 45.6 & 19.13 & 0 & 42.30 & 62.39 \\
\hline & 75 & 0 & 0 & 0 & 66.83 & 100 \\
\hline & 100 & 0 & 0 & 0.2 & 100 & 100 \\
\hline \multirow{4}{*}{$\mathrm{FeCl}_{3}$} & 25 & 0 & 0 & 0 & - & - \\
\hline & 50 & 39.7 & 0 & 3 & 93.46 & 8.83 \\
\hline & 75 & 24.51 & 0 & 3 & 83.74 & 100 \\
\hline & 100 & 42.2 & 0 & 1 & 61.11 & 20.39 \\
\hline
\end{tabular}

Different natural gums concentrations $(25,50,75$ and $100 \mathrm{mg} / \mathrm{L}$ ) were selected to determinate the optimal operating conditions in the coagulation-flocculation process. Nevertheless, this procedure also increases the COD by the aggregation of natural gums. The selected concentrations were fixed based on preliminary studies [26].

Galactomannans are the main forming element of all the natural gums. Among the tested gums, Prosopis laevigata seed gum and HPTAC-guar have the lowest ratio between manose and galactose. Hence, this ratio is used to select the most efficient gum using the COD reduction and sludge accumulation as key indicators. However, we have selected the HPTAC-guar because it can be obtained from commercial suppliers while the Prosopis laevigata should be extracted by a time consuming procedure.

The HPTAC-guar concentration was fixed to $25 \mathrm{mg} / \mathrm{L}$. This selection was done by considering the after mentioned indicators. Even when the concentration of HPTACguar fixed to $50 \mathrm{mg} / \mathrm{L}$ is more efficient, the inclusion of the natural gum in the reactor also increases the COD. Therefore, when lower gum concentration is used, both COD reduction and sludge production $(5.77 \%$ and 0 $\mathrm{mL} / \mathrm{L}$ ) are considered as acceptable for the second set of studies.

In this experiment, it was observed that beyond the optimum dose of coagulant-flocculant, the effect on the removal of physicochemical parameters is reversed. Indeed, instead of removing the evaluated parameters, all of them were increased. [26] reported that it is believed that biopolymers may provide sufficient organic load and instead of benefiting the process, they can increase the COD of the treated water.

The results showed that higher COD and turbidity removals were observed when HPTAC-guar was fixed to $50 \mathrm{mg} / \mathrm{L}$. Complementary, the FC and TC removal at this concentration are greater than $40 \%$. These results seem to be coincident with those presented by other studies. For example, Beltran et al. [40] have reported removal of coliforms between $96 \%$ and $94 \%$ using a natural gum extracted from Moringa oleifera. However, it is worth noticing that coliforms in their work reported was 400 to $800 \mathrm{CFU} / 100 \mathrm{~mL}$, while those found in the MWW treated in this work were of $2.7 \times 10^{7}$ and $8.48 \times 10^{6}$ $\mathrm{CFU} / \mathrm{mL}$.

A summary of all results obtained for all the different gums is shown in Table 3. The results achieved in this set of experiments were used to select the most adequate gum to treat the MWW. In general, all the gums derived from galactomannans were more efficient to reduce all the considered indicators (physicochemical and microbiological). In particular, higher COD removals were preferred over all other indicators. This is the main reason to select a coagulant-flocculant concentration between 25 and $50 \mathrm{mg} / \mathrm{L}$ as the optimal one. Moreover, a higher gum 
concentration increases the COD content that is considered as a negative result.

\subsection{Effect on the Physicochemical and Microbiological Removal by the HPTAC-Guar Concentration}

Based on the results obtained in the last experiment, a second set of experiments was designed using 5 different doses of HPTAC-guar (that was selected as the most adequate natural coagulant-flocculant). These doses were 25, 30, 40, 50 and $60 \mathrm{mg} / \mathrm{L}$.

All of them are within the range of those found as the more efficient ones in the previous experiment. This second concentration adjustment is proposed for obtaining a finest election of the HPTAC-guar concentration.

The best COD, turbidity, TC and FC removals were obtained by using natural rubber at a concentration of 50 and $60 \mathrm{mg} / \mathrm{L}$. However, one of the best HE removal was obtained when $30 \mathrm{mg} / \mathrm{L}$ of natural gum was selected. This gum concentration also provided similar changes in the physicochemical parameters to those obtained when gum concentrations were 50 and $60 \mathrm{mg} / \mathrm{L}$. The results obtained showed that removals obtained with natural rubber are higher than those obtained with $\mathrm{FeCl}_{3}$, Aguilar et al. [41] reported COD removal efficiencies of $86 \%$ using Iron salts at a dose of $100 \mathrm{mg} / \mathrm{L}$. All these experiments were carried out by triplicate.

A simple variance analysis showed that no significant differences are observed when gum concentration is varied from 25 to $60 \mathrm{mg} / \mathrm{L}$ (Figure 3).

Particularly, COD removals are similar for all the cases considered in this experiment (Figure 3(a)). However, all microbiological indicators were efficiently removed when HPTAC-guar was fixed between $30 \mathrm{mg} / \mathrm{L}$ and 50 $\mathrm{mg} / \mathrm{L}$ (Figure 3(b)). Indeed, HE was completely removed while TC and FC were eliminated above $80 \%$ in all these cases. Therefore, we have selected $30 \mathrm{mg} / \mathrm{L}$ as final HPTAC-guar concentration by two important criteria. The first one considers that when higher gum concentrations are in the reactor, more artificial COD is added to the experiment. The cost increase associated with the higher gum concentration was the second criterion considered here.

\subsection{Effect on the Physicochemical and Microbiological Removals by Modifying the Initial $\mathrm{pH}$ of the $\mathrm{MWW}$ with $\mathrm{Ca}(\mathrm{OH})_{2}$}

The adjustment of $\mathrm{pH}$ can be used to improve the coagulation-flocculation efficiency. This can be done using several chemical compounds. In particular, $\mathrm{Ca}(\mathrm{OH})_{2}$ has been reported as an efficient coagulant [42] and can modify the $\mathrm{pH}$ up to 12.5 .

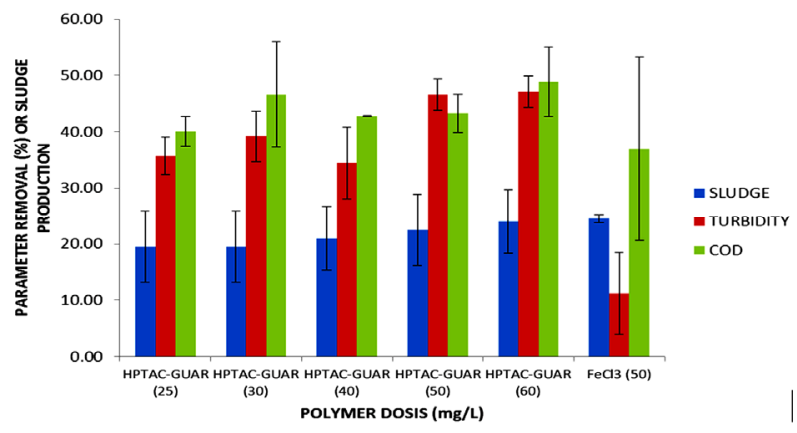

(a)

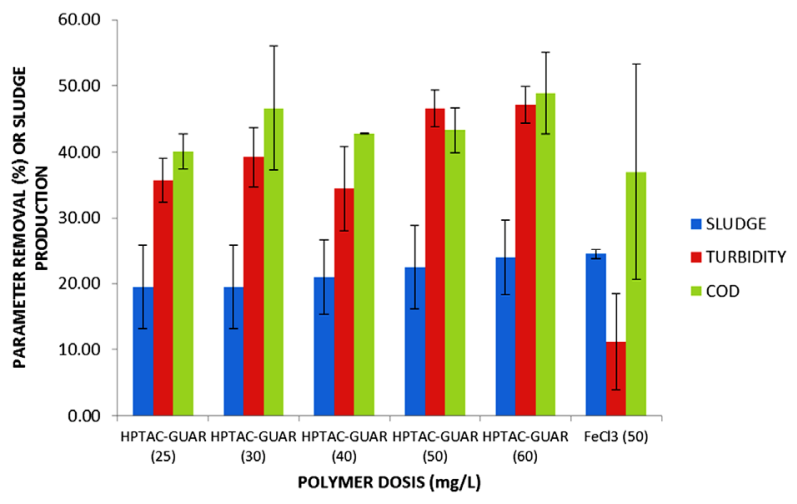

(b)

Figure 3. Removal of physicochemical (a) and microbeological (b) parameters in MWW after coagulation-flocculation process using HPTAC-guar at different concentrations.

The $\mathrm{pH}$ modification by $\mathrm{Ca}(\mathrm{OH})_{2}$ also alters the ideal condition for growing of TC, FC and HE (Table 4). Therefore, to add a controlled dose of $\mathrm{Ca}(\mathrm{OH})_{2}$ can improve the coagulation-flocculation efficiency and can serve to reduce the microbiological indicators. The following table shows the relationship between the volume of $\mathrm{Ca}(\mathrm{OH})_{2}$ added to the reactor and the modification of either microbiological and physicochemical parameters. In this experimental phase, the second batch of MWW was used.

When the initial $\mathrm{pH}$ of the MWW is used (no artificial $\mathrm{pH}$ adjustment), the COD removal is $1 \%$. However when $\mathrm{pH}$ is adjusted to 12.5 , this indicator is increased up to $80 \%$. Results obtained in this part showed a direct relationship between the $\mathrm{Ca}(\mathrm{OH})_{2}$ volume and the COD removal.

Turbidity variation showed a similar behavior to the one gotten for COD (from $10 \%$ to $78 \%$ when $\mathrm{pH}$ is adjusted from 7.8 to 12.5 ). All the microbiological indicators were improved. Indeed, all of them (TC and FC) were completely eliminated in all the cases when the $\mathrm{Ca}(\mathrm{OH})_{2}$ was in the reaction. However, an important negative effect is the increase of sludge volume when $\mathrm{Ca}(\mathrm{OH})_{2}$ is in the reactor. The $\mathrm{pH}$ adjustment from 7.8 to 12.5 increased the sludge volume in almost $3100 \%$. 
Table 4. Removal of physicochemical and microbiological parameters in MWW, changing the $\mathrm{pH}$ value with $\mathrm{Ca}(\mathrm{OH})_{2}$.

\begin{tabular}{ccccccc}
\hline pH & $\begin{array}{c}\text { Sol. of } \\
\mathbf{C a}(\mathbf{O H})_{2} \\
\mathbf{4 0} \mathbf{~ m g} / \mathbf{L}\end{array}$ & $\begin{array}{c}\text { COD } \\
\text { removal } \\
\mathbf{( \% )}\end{array}$ & $\begin{array}{c}\text { Turbidity } \\
\text { removal } \\
\mathbf{( \% )}\end{array}$ & $\begin{array}{c}\text { Sludge } \\
\text { formation } \\
\mathbf{( m L / L )}\end{array}$ & $\begin{array}{c}\text { TC } \\
\text { removal } \\
\mathbf{( \% )}\end{array}$ & $\begin{array}{c}\text { FC } \\
\text { removal } \\
\mathbf{( \% )}\end{array}$ \\
\hline 7.8 & 0 & 1.22 & 10.45 & 5 & 98.57 & 100.00 \\
8.8 & 11.5 & 46.34 & 19.61 & 11 & 100.00 & 100.00 \\
9.9 & 36.0 & 71.95 & 54.9 & 32 & 100.00 & 100.00 \\
10.6 & 75.0 & 68.9 & 62.74 & 55 & 100.00 & 100.00 \\
12.5 & 180.0 & 79.88 & 78.43 & 155 & 100.00 & 100.00 \\
\hline
\end{tabular}

\subsection{Effect on the Physicochemical and} Microbiological Removals by Coagulation
Flocculation Using HPTAC-Guar and
Modifying the MWW pH with $\mathrm{Ca}(\mathrm{OH})_{2}$

The complementary study that mixes the HPTAC-guar and $\mathrm{Ca}(\mathrm{OH})_{2}$ was used to understand if both the natural and the synthetic coagulant can improve the removal of either the physicochemical and microbiological indicators. Here, it is considered that $\mathrm{Ca}(\mathrm{OH})_{2}$ modifies the $\mathrm{pH}$ while HPTAC-guar combined with the hydroxile serve as coagulant/flocculant. This test used the $\mathrm{Ca}(\mathrm{OH})_{2}$ as a coagulant and HPTAC-guar as flocculant fixed the gum concentration at $25 \mathrm{mg} / \mathrm{L}$.

The COD removal in the neutral $\mathrm{pH}$ (without $\mathrm{pH}$ modification) was $11.7 \%$. However when $\mathrm{pH}$ is adjusted to 9.4, this removal is increased up to $50 \%$. Results obtained in this part the study showed a direct an increasing relationship between the $\mathrm{Ca}(\mathrm{OH})_{2}$ volume and the COD removal. Therefore, the gum has no evident contribution to the removal efficiency of both physicochemical and microbiological indicators (Figure 4).

Turbidity variation showed a similar behavior to the one gotten for the COD (from $17 \%$ to $43 \%$ when $\mathrm{pH}$ is varied from 7.7 to 9.4). The addition of $\mathrm{Ca}(\mathrm{OH})_{2}$ increased all the monitored parameters compared to the cases when only the HPTAC-guar (COD $36 \%$ to $47 \%$, Turbidity $37 \%$ to $42 \%$ ) is used as coagulant/flocculant. However, the same important negative effect of $\mathrm{Ca}(\mathrm{OH})_{2}$ regarding the increase of sludge is observed (15 to 50 $\mathrm{mL} / \mathrm{L}$ when $\mathrm{pH}$ is adjusted from its lowest value to the highest one) (Figure 4(a)). All the microbiological indicators were improved when both coagulants were in the reaction. Indeed, the $\mathrm{pH}$ showed a direct relationship in the removal of the TC (24\% to $71.5 \%)$ and HE (100\%) (Figure 4(b)).

It was observed that the higher removal in terms of the measured parameters is obtained by working at a $\mathrm{pH}$ of 9.4 (Figure 4(b)). Aguilar et al. [41], have reported that when working with iron and aluminum salts of modify-

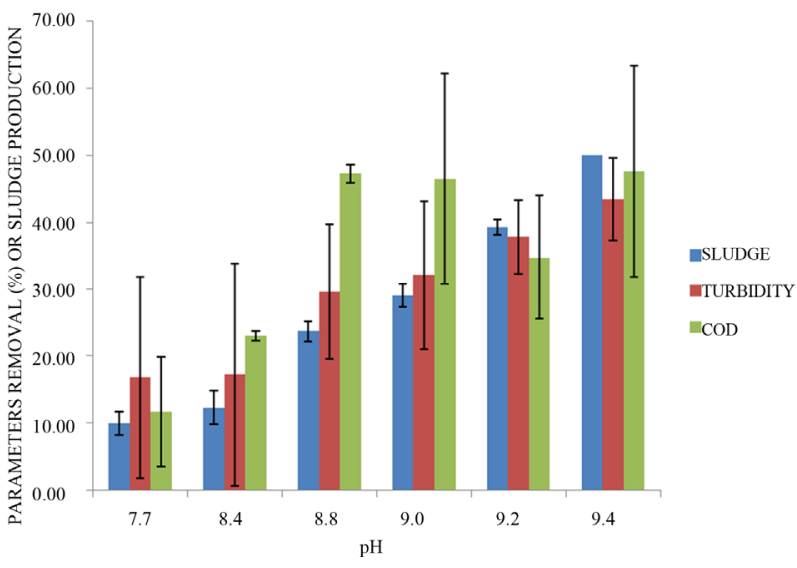

(a)

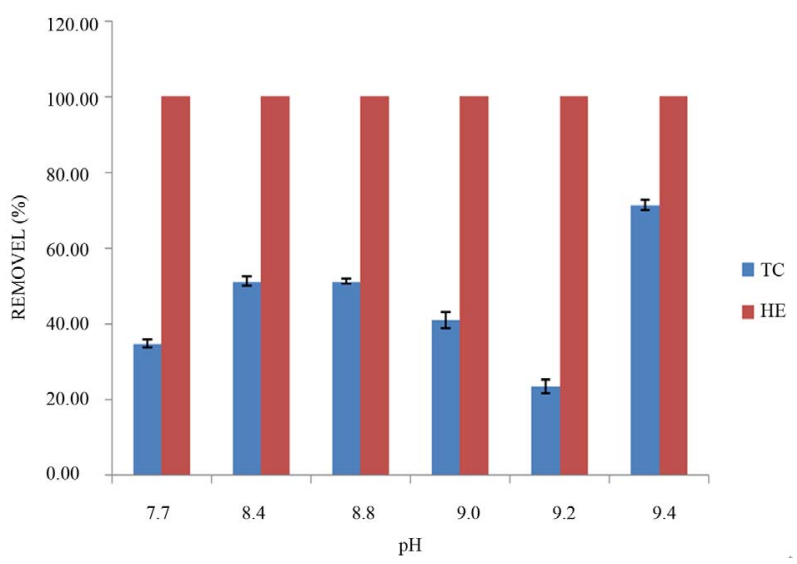

(b)

Figure 4. Removal of physicochemical (a) and microbiological (b) parameters in the MWW using $\mathrm{Ca}(\mathrm{OH})_{2}$ as coagulant and flocculant HPTAC-guar.

ing the $\mathrm{pH}$ in the process, reaches a maximum $\mathrm{pH}$ at which the improved process, in the case of this study was determined at $\mathrm{pH} 7$, higher $\mathrm{pH}$ the COD removal was diminished.

\section{Conclusion}

The use of biopolymer HPTAC-guar as a coagulant-flocculant agent showed an efficient removal of parameters such as COD and turbidity. A remarkable decrease of biological indicators was observed, even greater than that obtained when using the $\mathrm{FeCl}_{3}$. Another parameter that should be highlighted is that the sludge using the biopolymer is less than those obtained when using the $\mathrm{FeCl}_{3}$. It was observed that the removal of microorganisms can be very efficient, but does not reach the allowable limits in the Mexican Official Standards, so it is advisable to fit the process to another, such as ozonation to help reaching permitted limits. The change of $\mathrm{pH}$ by $\mathrm{Ca}(\mathrm{OH})_{2}$ in the coagulation-flocculation process was shown to have a positive influence on the removal of chemical and biological parameters. 


\section{Acknowledgements}

This work was partially supported by ICyT-DF Grant PICSO 10 - 8. We thank the San Juan Ixhuatepec Wastewater Treatment Plant the opportunity to use its raw wastewaters.

\section{REFERENCES}

[1] P. Mijaylova, L. Torres, E. Ramírez, S. López and L. Cardoso, "Characterization and Coagulation-Flocculation Treatability of Mexico City Wastewater Applying Ferric Chloride and Polymers," Water Science Technology, Vol. 34, No. 3-4, 1996, pp. 235-247.

[2] M. T. Orta de Velázquez, N. Rojas, J. Martínez and I. Monje, "Destruction of Helminth Eggs (Ascaris suum) by Ozone," Science \& Engineering, Vol. 26, No. 4, 2004, pp. 359-366.

[3] S. Toze, "PCR and the Detection of Microbial Pathogens in Water and Wastewater," Water Research, Vol. 33, No. 17, 1999, pp. 3545-3556. http://dx.doi.org/10.1016/S0043-1354(99)00071-8

[4] B. Jimenez, "Helminths (Worms) Eggs Control in Wastewater and Sludge," International Symposium on New Directions in Urban Water Management, 2007.

[5] B. Jimenez and C. Maya-Rendon, "Helminths and Sanitation. Communicating Current Research and Educational Topics and Trends," 2007.

[6] J. A. Barrios, B. Jimenez, O. Gonzalez, G. Salgado, L. Samaria and R. Iturbe, "Faecal Coliforms Destruction and Helmint Eggs in Physical-Chemical Sludges by Acid Means (In Spanish)," Proceedings of the XII FEMISCA National Congress, Morelia, 2000, pp. 683-692.

[7] S. Capizzi-Banas, M. Deloge, M. Remy and J. Schwartzbrod, "Liming as an Advanced Treatment for Sludge Sanitization: Helminth Eggs Eliminate Ion-Ascaris Eggs as Model," Water Research, Vol. 38, 2004, pp. 3251-3258. http://dx.doi.org/10.1016/j.watres.2004.04.015

[8] B. Jimenez, "Helminth Ova Control in Wastewater and Sludge for Agricultural Reuse," In: W. O. K. Grabow, Ed., Water Reuse New Paradigm towards Integrated Water Resources Management in Encyclopedia of Biological, Physiological and Health Sciences, Water and Health, II, Life Support System, EOLSS Publishers Co Ltd., UNESCO, 2008, pp. 429-449.

[9] S. Quinzaños, C. Dahl, R. Strube and R. Mujeriego, "Helmint Eggs Removal by Microscrening for Water Reclamation and Reuse," Water Science and Technology, Vol. 57, No. 5, 2008, pp. 715-720. http://dx.doi.org/10.2166/wst.2008.171

[10] M. E. Sengupta, S. M. Thamsborg, T. J. Andersen, A. Olsen and A. Dastard, "Sedimentation of Helminth Eggs in Water," Water Research, Vol. 45, No. 15, 2011, pp. 4651-4660.

[11] J. Nouri, A. H. Mahvi, R. Saeedi, K. Dindarloo and M. Rafiee and S. Dobaradaran, "Purification of and Removal Acaris and Fasciola Hepatica Eggs from Drinking Water Using Roughing Filters," Korean Journal of Chemical
Engineering, Vol. 25, No. 3, 2008, pp. 501-504. http://dx.doi.org/10.1007/s11814-008-0084-4

[12] N. Cabirol, M. Rojas and A. Noyola, "Removal of Helminth Eggs and Faecal Coliforms by Anaerobic Termophilic Sludge Digestion," Water Science and Technology, Vol. 45, No. 10, 2002, pp. 269-274.

[13] M. von Sperling, V. H. Freire and C. A. de Lemos Chernacaro, "Performance Evaluation of a UASB-Activated Sludge System Treating Municipal Wastewater," Water Science and Technology, Vol. 43, No. 11, 2001, pp. 323328.

[14] E. J. La Mota, E. Silva, A. Bustillos, H. Padron and J. Luque, "Combined Anaerobic/Aerobic Secondary Municipal Wastewater Treatment: Pilot Plant Desmostration of the UASB/Aerobic Solids Contact System," Journal of Environmental Engineering-ASCE, Vol. 133, No. 4, 2007, pp. 397-403.

[15] J. Guo, J. Wang, D. Cui, L. Wang, F. Ma, C. Chang and J. Yang, "Application of Bioaugmentation in the Rapid Start-Up and Stable Operation of Biological Processes for Municipal Wastewater Treatment at Low Temperatures," Bioresource Technology, Vol. 101, No. 17, 2010, pp. 6622-6629.

[16] R. Reinoso, L. A. Torres and E. Bécares, "Efficiency of Natural Systems for Removal of Bacteria and Pathogenic Parasites from Wastewater," Science of the Total Environment, Vol. 395, No. 2-3, 2008, pp. 80-86.

[17] Y. Liu, T. Yang, D. Yuan and X. Wu, "Study of Municipal Wastewater Treatment with Oystert Shell as Biological Aerated Filter Médium," Desalination, Vol. 254, No. 1-3, 2010, pp. 149-153.

[18] N. Rojas-Valencia, "Research on Ozone Application as Disinfectant and Actions Mechanisms on Wastewater Microorganisms. Science against Microbial Pathogens: Communicating Current Research and Technological Advances," Microbiology Book Series-Number 3, Vol. 1, FORMATEX (A. Mendez-Vilas Edit), España, 2011, pp. 263271.

[19] C.-H. Lin, R.-F. Yu, W.-P. Cheng and C.-R. Liu, "Monitoring and Control of UV and $\mathrm{UV}-\mathrm{TiO}_{2}$ Disinfections for Municipal Wastewater Reclamation Using Artificial Neural Networks," Journal of Hazardous Materials, Vol. 209210, No. 1, 2012, pp. 348-354.

[20] Z. Bhatti, Q. Mahmood, I. Raja, A. Malik, N. Rachis and $\mathrm{D}$. $\mathrm{Wu}$, "Integrated Chemical Treatment of Municipal Wastewater Using Waste Hydrogen Peroxide and Ultraviolet Light," Physics and Chemistry of the Earth, Vol. 36, No. 9-11, 2011, pp. 459-464.

[21] J. García, E. Bandala and B. Corona, "Inactivation of Helminth Eggs by Homogeneus Photocattalysis," Aquaforum, Vol. 49, No. 1, 2008, pp. 14-18.

[22] L. Semerjian and G. Ayoub, "High-pH-Magnesium Coagulation-Flocculation in Wastewater Treatment," Advances in Environmental Research, Vol. 7, No. 2, 2003, pp. 389-403.

[23] A. Bazer-Bachi, E. Puech-Coste, R. Ben Aim and J. L. Probst, "Modélisationmathé Matique du taux de Coagulant dans une Station de Traitementd_eau," Revue des Sciences de l_Eau, Vol. 3, No. 4, 1990, pp. 377-397. 
[24] A. Ahmad, S. Wong, T. Teng and A. Zuhairi, "Optimization of Coagulation-Flocculation Process for Pulp and Paper Mill Effluent by Response Surface Methodological Analysis," Journal of Hazardous Materials, Vol. 145, No. 1-2, 2007, pp. 162-168.

[25] Y. López-Franco, F. Goycoolea, M. Valdez and A. Calderón de la Barca, "Goma de Mezquite: Una Alternativa al uso Industrial (Mesquite Gum: Analternativeto Industrial Use," Interciencia, Vol. 31, No. 3, 2006, pp. 183188.

[26] S. Carpinteyro-Urbán, J. Yañez and L. Torres, "Coagulation Flocculation of Wastewaters Employing Guar, Locust Bean and Mesquite Gums, as Well as Opuntia Mucilage," Proceedings of the 2nd IWA Mexico Young Water Professional Conference, Querétaro, 2010.

[27] L. G. Torres, S. Carpinteyro-Urbán and M. Vaca, "Use of Prosopis Laevigata Seed Gum and Opuntia Ficus-Indica Mucilage for Treatment of Municipal Wastewaters by Coagulation-Flocculation," Natural Resources, in press, 2011.

[28] L. G. Torres, S. Carpinteyro-Urbán and L. J. Corzo-Rios, "Use of Annona Diversifolia and A. Muricata Seeds as Source of Natural Coagulant-Flocculant Aids for the Treatment of Wastewaters," Submitted to Indian Journal of Biotechnology, 2012.

[29] S. Carpinteyro-Urbán, M. Vaca and L. Torres, "Can Vegetal Biopolymers Work as Coagulant-Flocculant Aids in the Treatment of High-Load Cosmetic Industrial Wastewaters? Submitted to Water, Air and Soil Pollution," 2012.

[30] S. Carpinteyro-Urbán, M. Vaca and L. Torres, "Use of Response Surface Methodology in the Optimization of Coagulation-Flocculation of Wastewaters Employing Biopolymers. Submitted to International Journal of Environmental Research," 2012.

[31] B. Bina, H. Movahedian and I. Kord, "The Effect of Lime Stabilization on the Microbiological Quality of Sewage Sludge," Iranian Journal of Environmental Health and Science Engineering, Vol. 1, No. 1, 2004, pp. 34-38.

[32] SEMARNAT 1997 NOM-003-ECOL-1997, "Establish- ing Limits for Maximum Permissible Pollutants Treated Wastewater Who Reuse in Public Services. (In Spanish), México," 1997.

[33] SEMARNAT 1996 NOM-001-ECOL-1996, "Establishing the Maximum Allowable Discharge of Pollutants in Sewage Water and Domestic Goods. (In Spanish), México," 1996.

[34] SECOFI 1999 NMX-AA-113-SCFI-1999, "Analysis of Water-Determination of Helminth Eggs-Test Method (in Spanish), México," 1999.

[35] SECOFI 2006 NMX-AA-102-SCFI-2006, "Water Quality Detection and Enumeration of Coliform Organisms, Thermotolerant Coliform Organisms and Presumptive Escherichia coli-Membrane Filtration Method. (in Spanish), México," 2006.

[36] J. L. Soulsby, "Parasitology and Parasitarial Diseases in Domestic Animals," 7th Edition (In Spanish), (Interamericana, ed). Mexico, 1987.

[37] H. W. Brown and F. A. Neva, "Clinical Parasitology," 5th Edition (In Spanish), Editorial Interamericana, Mexico, 1985.

[38] WHO, "Integrated Guide to Sanitary Parasitology. (WHOEM/CEH/121/E Ed)," Amman-Jordan, 2005.

[39] R. Romero, "Human Microbiology and Parasitology. Ethiological Bases for the Infection Diseases. (In Spanish)," (Medica-Panamericana, ed). Mexico, 1993.

[40] J. Beltran and J. Sánches, "Improvement of Flocculation Process in Water Treatment by Using Moringa Oleífera Seeds Extract," Proceedings or the Water \& Industry 2011-IWA International Conference, Valladolid, 2011.

[41] M. I. Aguilar, J. Sáez, M. Lloréns, A. Soler, J. F. Ortuño, V. Messeguer and A. Fuentes, "Improvement of Coagulation-Flocculation Process Using Anionic Polyacrylamide as Coagulant Aid," Chemosphere, Vol. 58, No. 1, 2005, pp. 47-65

[42] D. Georgiou, A. Aivazidis, J. Hatiras and K. Gimouhopoulos, "Treatment of Cotton Textile Wastewater Using Lime and Ferrous Sulfate," Water Research, Vol. 37, No. 9, 2002, pp. 2248-2250. 